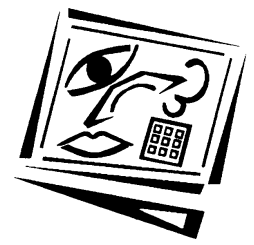

\title{
A bridge too far? Explaining beginning teachers' use of ICT in Australian schools
}

\begin{abstract}
University of Notre Dame
This paper discusses some of the findings from a recent longitudinal study that examined how 35 beginning teachers used information and communications technologies (ICT) in the first three years of their teaching. The research, set in Western Australia, adopted a mixed method approach to help understand the role that ICT played in the evolving pedagogical practices of the teachers involved. The study found that beginning teachers articulated pedagogical beliefs that aimed to engage their students in active meaning making. It also found that these teachers were competent in the use of a basic suite of ICT software. However, pedagogical beliefs that resonate with contemporary learning theory and operational ICT competence did not translate into practices that synergised pedagogical, content and technological knowledge. The teachers involved in the study did not use ICT in ways that were consistent with their stated pedagogical beliefs. The relationships between teachers' beliefs and their pedagogical and technological knowledge are discussed within the contexts of different school settings. A framework is presented that emphasises the need for teachers and school leaders to make connections across pedagogical and technological domains.
\end{abstract}

Frank Bate

\section{Introduction}

It has been suggested that information and communications technologies (ICT) have been fired at teaching and learning from point blank range, forever disturbing the existing order in education (Kompf, 2005). Each new wave of ICT innovation carries with it a barrage of opportunities and risks that challenge and constrain educators who seek to optimise the use of ICT for teaching and learning. ICT comprise part of a subset of emerging technologies that include information and communication devices (e.g. computers, interactive whiteboards, mobile phones, iPads, television, etc.) and the software that enables these devices to function (MCEETYA, 2006). The integration of ICT into classroom practices can incorporate a broad range of activities from those designed to encourage students to consume knowledge (e.g. teachers' use of presentation software, DVDs or podcasting) to those designed to develop students' abilities to produce their own knowledge (e.g. development of a reflective blog, collaborative wiki site or e-portfolio). ICT, therefore, have the potential to enhance both teaching and learning and it is for the teacher to decide if, when and how this can be done.

The proliferation of ICT at home and in workplaces (Somekh, 2007) presents opportunities for teachers to develop learning environments that encourage students to be more motivated, behave appropriately in the classroom, and generally engage more effectively in the learning process. However, there is widespread consensus in 
the research literature indicating that teachers tend not to take full advantage of these opportunities (Cuban, 2001; Groff \& Mouza, 2008; Levin \& Wadmany, 2008; Pegg, Reading \& Williams, 2007; Sutherland, Robertson \& John, 2009; Voogt, 2008). One of the reasons for the unenthusiastic response to ICT amongst teachers might be that technological knowledge is either absent or lacking in the processes that underpins teachers' planning (Webb \& Cox, 2004). This idea has recently been developed by Mishra and Koehler (2006) and Harris, Mishra and Koehler (2009), who propose that there is a tendency for teachers not to synergise their content and pedagogical knowledge with their technological knowledge, and that this can result in mundane ways in which ICT are used in the classroom.

The purpose of the research that underpinned this paper was to attain an empathetic understanding of beginning teachers in their workplaces. A cohort of 35 beginning teachers was tracked over a three year timeframe between January 2007 and November 2009. These 35 volunteered for the study, all being new to the teaching profession, having graduated in the year before data collection commenced. The focus on beginning teachers as they established themselves in the profession was purposeful. It is proposed that beginning teachers might provide a window into the future use of ICT in education. Many teaching graduates now enter the profession with a basic ICT skill set having undertaken targeted learning that deals with ICT skills and pedagogy as part of their undergraduate studies (Steketee, 2005). In addition, most of the recent generation of teaching graduates have grown up with digital technologies and it is likely that these individuals may be open to using ICT in their own teaching. These ideas have been developed in recent literature (e.g. Gao, Wong, Choy \& Wu, 2010).

In Australia, a targeted ICT policy agenda is in place to assist teachers to harness new technologies (Experience the Digital Education Revolution, 2009; Gillard, 2008). However, it is reported that teachers are sceptical of its value in the classroom (Pegg, et al., 2007). For example, a survey of 1,500 teachers commissioned by the Western Australian Department of Education and Training (2006) reported that, although $95 \%$ of teachers had used a basic suite of ICT applications, only $18 \%$ regularly used ICT in the classroom on a weekly to daily basis. Further, of the $18 \%$ who used ICT regularly, most did so in the preparation of their lessons or to improve students' computer skills. In a study involving just over 2,500 students, Russell, Bebell and O'Dwyer (2005) arrived at similar conclusions, reporting that teachers (particularly beginning teachers) used ICT for administration and preparation, but seldom in student-centred ways.

It is understandable that teachers have been the focus of much of the research into the use of ICT in schools. Teachers have a good deal of autonomy over if, and how, to introduce changes to their practices (Judson, 2006), and as a result, teachers' beliefs (Buehl \& Fives, 2009; Ertmer, 2005; Judson, 2006), attitudes (Demetriadis et al., 2003; Kadel, 2005; Vannatta \& Fordham, 2004), values (Phelps \& Maddison, 2008) selfefficacy in using ICT (Jamieson-Proctor, Burnett, Finger \& Watson, 2006) and actions (Auld et al., 2008; Freebody \& Muspratt, 2007; Russell, et al., 2005) have all come under the research microscope. However, teachers operate in a range of socio-cultural settings (Goos, 2005) where issues such as interpreting the curriculum, assessing student capabilities, managing student behaviour, and parent liaison all impact on the way in which they respond to reform. Schools themselves are political environments where individual agendas find expression, and interpreting and responding to educational reform is contestable (Somekh, 2009). The result is that the use of ICT in schools is complex and multi-faceted (Brown, 2004). A range of ICT approaches and 
avoidance strategies have emerged that are sometimes difficult to interpret. According to Dede (2008), the general public is confused about what types of ICT (if any) are effective in education. Auld et al (2008, p. 10) extends this observation to the teaching profession itself:

Teachers are confronted with an eclectic array of theories and instructional designs and bombarded with confusing, even romantic views on what technology is capable of delivering.

It would seem that, whilst there is a vast amount of research into the use of ICT in education, much of this is scattered and a synthesis of the research has not yet been achieved (Voogt \& Knezek, 2008). This paper sets out to understand how 35 beginning teachers interpreted this potentially confusing and rapidly changing ICT environment. In doing so, it seeks to discern how and why ICT were used or avoided in a specific set of contexts.

\section{Building bridges: A framework for understanding how and why ICT are used or avoided}

The concept of pedagogical reasoning, originally conceived by Shulman (1987), embodies the idea that autonomous teaching professionals are empowered to make moment to moment decisions on what is in the best interests of their students in terms of their academic and social development. In a study of 220 student teachers, Fullan (1993, p. 12) found that most entered the teaching profession with a "moral purpose" to make a difference to students' lives. Pedagogical reasoning provides avenues for students to achieve their potential and teachers to realise their moral purpose.

Shulman's (1987) ideas have recently been extended to help explain the thinking that underpins decisions around the use of ICT (Harris, et al., 2009; Mishra \& Koehler, 2006; Webb \& Cox, 2004), particularly as this relates to the synergy between pedagogical, content and technological knowledge. Teachers engage in pedagogical reasoning in planning, implementing and reflecting upon their use of ICT where the potential of ICT is considered in the context of risks (e.g. student capabilities, maturity, quality of available resources), teacher and school goals, competing priorities and opportunity costs. Pedagogical reasoning provides opportunities for teachers to make connections with their schools by accessing equipment, infrastructure and support, following procedures and so on. The concept of pedagogical reasoning is situated at the centre of the framework that guided the research (shown as Figure 1).

The beliefs that teachers hold about teaching, learning and ICT itself form an important foundation stone for the way in which their various types of knowledge are expressed. For example, teachers with beliefs about learning that emphasise collaboration may choose to explore the transformative potential of ICT, building their knowledge base and reflecting upon their own practices in the light of the communicative opportunities that ICT might present (e.g. Web 2.0). Teachers with this orientation may see students' engagement with ICT as an intellectual partnership in which ICT is used as a cognitive tool (Jonassen, 2002) to extend students' learning and creativity. Other teachers may hold beliefs about learning that emphasise the importance of the teacher as an efficient means of distributing knowledge. In these circumstances it is likely that ICT is equated with productivity (Maddux, LaMont Johnson \& Willis, 2001), as an opportunity to complement or amplify existing teaching approaches (Hughes, Thomas \& Scharber, 2006), or simply as a reward for early 
finishers. Of course many teachers use both teacher- and learner-centred pedagogies in the classroom or adopt a shifting approach in response to their context (e.g. student capabilities, needs and preferences or the demands of specific content areas). Optimising the use of ICT in these circumstances requires well developed pedagogical and technological knowledge.

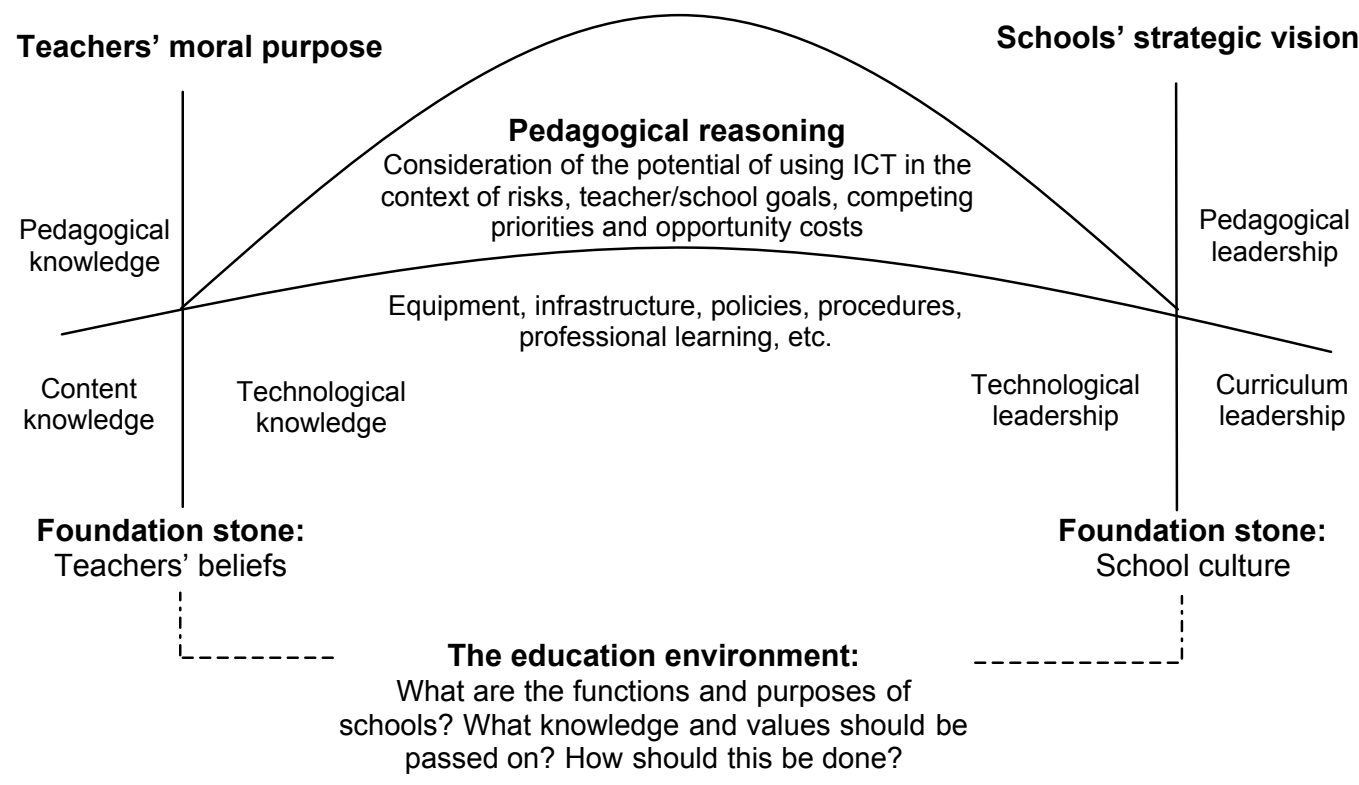

Figure 1: Innovation through ICT expressed as a bridge between teacher and school

How teachers' beliefs impact upon their pedagogical, content and technological knowledge, and ultimately their practices is best understood in the context of their socio-cultural setting (Goos, 2005; Lim \& Chai, 2008). For example, if a school adopts an approach to ICT integration based upon student access to a computer laboratory once per week, it is likely that a teacher's beliefs about the student-centred use of ICT across the curriculum will not be enacted. Teachers, enthused about using ICT at the point of need (i.e. the classroom) may experience feelings of isolation and frustration without the support of their school. Hofer $(2006$, p. 90) proposes that teachers may feel some "cognitive dissonance" arising from endorsing world views that are incongruent with the practices adopted by the educational systems in which they are placed. The research literature on ICT integration cites many examples of small scale innovations that are ultimately unsustainable (Fishman, Marx, Blumenfeld, Krajcik \& Soloway, 2004). The culture of the school provides another important foundation stone for the way in which its curriculum, pedagogical and technological support are expressed. In the same way teachers' beliefs shape ICT practices at the level of the individual, a school's culture sets the conditions for ICT practices at the level of the organisation. It is useful, therefore, for teachers to build bridges between their own beliefs and practices and the school's strategic vision. Similarly, it is useful for schools to build bridges with their constituents to achieve their strategic vision.

Relationships between individual teachers, dominant cultures and school leadership can sometimes be turbulent (Somekh, 2007) particularly in reform environments such 
as that which is characterised by the Digital Education Revolution in Australia. The actions of all participants in the process of education (parents, students, teachers and administrators) are shaped by their fundamental beliefs about the function and purpose of education including their beliefs about what knowledge should be passed on (curriculum), how it is passed on (pedagogy) and how judgments are made about the extent to which it is successfully passed on (assessment). The research that underpins this paper conceived the evolving pedagogical approaches of early career teachers as a process of building bridges with their students, schools and the wider community. The underlying beliefs, knowledge and actions of the participants of the research are therefore described in the context of the socio-cultural environments in which they were set.

\section{Methodology}

Seven research questions underpinned the study, focusing on the knowledge, beliefs, dispositions and skills of participating teachers. One of these questions sought to examine the impact of the school environment, and this is particularly pertinent to the development of the bridge framework central to this paper: What aspects of the sociocultural environment impacts on beginning teachers' pedagogical beliefs, and their knowledge, dispositions and skills in using ICT? Responding to this, and other research questions, called for a mix of methods comprising of a quantitative approach for gathering baseline data on beginning teachers' pedagogical beliefs and a qualitative approach for helping to understand how participants' beliefs related to their knowledge, attitudes, self-perceptions and skills within their socio-cultural context. A Pedagogical Beliefs Questionnaire (PBQ) was administered at the inception (January 2007, $\mathrm{n}=35$ ) and conclusion (November 2009, $\mathrm{n}=20$ ) of the study. The questionnaire, which was based upon instruments developed by Frid (2000), Goos and Bennison $(2002,2007)$ and Fives and Buehl (2005), provided useful baseline data on participants' beliefs about teaching, learning and ICT. Cronbach's alpha was used to calculate the reliability of both iterations of the questionnaire which were 0.724 at inception and 0.717 at conclusion.

The questionnaire contained 35 statements grouped under five sub-scales that equate with the attributes of meaningful learning as described by Jonassen, Peck and Wilson (1999): learning is active, cooperative, constructive, authentic and intentional. Participants were invited to indicate their level of agreement with each of the statements in the questionnaire by responding to a five point Likert type scale (strongly agree, agree, undecided, disagree, strongly disagree). Responses to each statement were given a score where $5=$ strongly agree, $4=$ agree, $3=$ undecided, $2=$ disagree, $1=$ strongly disagree. Statements were designed to both support and contradict the identified attributes of meaningful learning. The questionnaire contained 19 statements that supported the identified attributes of meaningful learning and 16 that did not. Responses for the 16 items that contradicted the identified attributes of meaningful learning were inverted and mean scores calculated for participants. The maximum possible mean score was 5.0 and to register this, a participant would have strongly agreed with the 19 items that complied with the identified attributes of meaningful learning and strongly disagreed with the 16 items that challenged these attributes.

The research also embraced a qualitative-interpretive approach through interviewing and observation. The primary purpose of interviewing was to understand participants' 
pedagogical and technological knowledge, and their dispositions towards ICT in the context of their stated pedagogical beliefs. To provide an authentic depiction of the way in which beginning teachers use ICT in their teaching, participants were also observed in their naturalistic classroom settings. Interviews and observations were conducted on an annual basis during the study in an attempt to discern changes to participants' pedagogical practices and also in their use of ICT.

Only participants who had completed the PBQ were invited to take part in the interview process. Fifty eight participant interviews took place over the period of the study, with the numbers gradually diminishing from 28 in 2007, to 16 in 2008 and 14 in 2009. Only participants who had been interviewed in the previous year were invited to continue in the interviewing process. Over the period of the study, 30 observations were carried out. Observations were conducted on a voluntary basis either immediately before or after interviewing. Eight of 28 interviewees were observed in 2007; all 16 were observed in 2008 and all 14 were observed in 2009. An Observation Protocol based upon that developed by Judson (2006) was used to help focus and standardise observations. During visits to schools, other key personnel were interviewed including principals, deputy principals, ICT coordinators and teacher librarians. Data were also collected on the infrastructure and equipment that was available to the teachers involved in the study.

Participants in the research operated in unique physical and socio-cultural contexts, dealt with different challenges, and had a range of experiences with ICT over the period of the study. The school settings of most participants changed during data collection (e.g. some participants changed school and some schools changed leadership) and this contributed to the uniqueness of each participant's experiences.

\section{Findings}

Responses to the PBQ at the inception and conclusion of the study indicate that participants held beliefs that resonated with the principles of meaningful learning as identified by Jonassen, Peck and Wilson (1999). The mean score for participants at inception was $3.6(n=35)$ with a slight increase to $3.7(n=20)$ at conclusion. However, beliefs tended not to translate into creative, student-centred applications of ICT. The paper explores relationships between beginning teachers' socio-cultural contexts and the development of their pedagogical practices.

The journeys of three participants, Dawn, Mike and Rashmi (pseudonyms used), represent three distinct ICT typologies: deprived ICT environments where limited ICT are provided in the classroom for teacher or student use; modest ICT environments in which teachers are typically equipped with a computer and a projection device to assist them in their teaching; and adequate ICT environments in which teachers and students are provided with reasonable access to ICT that can underpin teacher- and learner-centred pedagogical approaches. Of the 14 beginning teachers interviewed and observed in 2009, five were from deprived ICT environments, four were situated in modest ICT settings and five had access to adequate ICT. Therefore, the ICT environments encountered by Dawn, Mike and Rashmi were broadly representative of the sample at the conclusion of the study. Table 1 describes these typologies. Information on sector, year level, class size, and features of school leadership are also provided. 
Table 1: Typical ICT environments inhabited by Dawn, Mike and Rashmi (pseudonyms used)

\begin{tabular}{|c|c|c|c|c|c|}
\hline Typology & Sector & $\begin{array}{l}\text { Year } \\
\text { level }\end{array}$ & $\begin{array}{l}\text { Avg } \\
\text { class } \\
\text { size }\end{array}$ & $\begin{array}{l}\text { Equipment/ } \\
\text { infrastructure }\end{array}$ & $\begin{array}{c}\text { Features of the school } \\
\text { leadership }\end{array}$ \\
\hline \multirow[t]{2}{*}{$\begin{array}{l}\text { Deprived. } \\
\text { Participant: } \\
\text { Dawn } \\
\text { Age: }>24 \\
\text { Female }\end{array}$} & $\begin{array}{l}\text { Public } \\
(2007 \\
\text { and } \\
2008)\end{array}$ & 9 & 10 & $\begin{array}{l}\text { Poorly equipped for teacher- } \\
\text { directed learning (e.g. no } \\
\text { projection device provided in } \\
\text { the classroom). One computer } \\
\text { provided in the classroom } \\
\text { which was deemed insuffic- } \\
\text { ient for students to engage in } \\
\text { self-directed work. Access to } \\
\text { a shared laboratory (8 } \\
\text { computers) once per week. }\end{array}$ & $\begin{array}{l}\text { Geographically isolated } \\
\text { school which focused on } \\
\text { increasing literacy and } \\
\text { numeracy outcomes. } \\
\text { Challenges associated } \\
\text { with building and } \\
\text { maintaining appropriate } \\
\text { technical infrastructure } \\
\text { proved to be a barrier. }\end{array}$ \\
\hline & $\begin{array}{l}\text { Public } \\
(2009)\end{array}$ & $\begin{array}{c}1 \\
\text { and } \\
2\end{array}$ & 26 & $\begin{array}{l}\text { Poorly equipped for teacher- } \\
\text { directed learning (e.g. no } \\
\text { projection device provided in } \\
\text { the classroom). Two } \\
\text { computers provided in the } \\
\text { classroom but rarely used for } \\
\text { students to undertake self- } \\
\text { directed work. }\end{array}$ & $\begin{array}{l}\text { School located in an area } \\
\text { of low socio-economic } \\
\text { status, and other issues } \\
\text { (e.g. maintaining } \\
\text { buildings, combating } \\
\text { bullying, truancy, } \\
\text { attracting and retaining } \\
\text { staff) have taken priority. }\end{array}$ \\
\hline $\begin{array}{l}\text { Modest. } \\
\text { Participant: } \\
\text { Mike } \\
\text { Age: >24 } \\
\text { Male }\end{array}$ & $\begin{array}{l}\text { Indep- } \\
\text { endent } \\
\text { (2007- } \\
2009)\end{array}$ & 7 & 18 & $\begin{array}{l}\text { Equipped for teacher-directed } \\
\text { learning. Laptop computer } \\
\text { and fixed interactive } \\
\text { whiteboard (2008 onwards) } \\
\text { available to the teacher in } \\
\text { addition to } 3 \text { computers in the } \\
\text { classroom for student use. } \\
\text { Access to a shared laboratory } \\
\text { (16 computers) once per } \\
\text { week. }\end{array}$ & $\begin{array}{l}\text { School leadership had a } \\
\text { limited understanding of } \\
\text { how ICT could enhance } \\
\text { student learning and } \\
\text { apart from rolling out } \\
\text { interactive whiteboards, } \\
\text { did not develop strategies } \\
\text { that encouraged student- } \\
\text { centred ICT use. }\end{array}$ \\
\hline $\begin{array}{l}\text { Adequate. } \\
\text { Participant: } \\
\text { Rashmi } \\
\text { Age: }>24 \\
\text { Female }\end{array}$ & $\begin{array}{l}\text { Catholic } \\
(2007- \\
2009)\end{array}$ & 4 & 27 & $\begin{array}{l}\text { Equipped for teacher- and } \\
\text { student-directed learning. } \\
\text { Laptop computer and fixed } \\
\text { interactive whiteboard } \\
\text { available to the teacher in } \\
\text { addition to } 6 \text { computers in the } \\
\text { classroom for students to } \\
\text { engage in self-directed work. } \\
\text { Access to a shared laboratory } \\
(31 \text { computers) on demand. }\end{array}$ & $\begin{array}{l}\text { School leadership } \\
\text { supportive of ICT } \\
\text { integration and provided } \\
\text { ample opportunities for } \\
\text { professional learning and } \\
\text { discussion of ICT ideas. A } \\
\text { 1:1 laptop environment is } \\
\text { now supported. }\end{array}$ \\
\hline
\end{tabular}

The professional journeys of Dawn, Mike and Rashmi are now discussed.

\section{Dawn}

Dawn was in her early 20s at the time of gaining her first appointment in a regional secondary school. The circumstances surrounding her appointment were unusual in two ways. First, although she was primary-trained, the position offered was responsible for a mixed Year 8/9 group (middle school); and secondly, she was offered the position on the Friday before the school year commenced early in the following week, and therefore had to make a quick decision on whether to take up the appointment. The school itself was remote comprising of a largely indigenous 
population. Dawn initially had a class of 10 indigenous students who, in her view, were "a little bit socially immature" and "more or less at Year 5 level" (Dawn, 2007).

In 2007, Dawn's philosophy of teaching centred on "providing students with the tools they need to succeed in life and to recognise and achieve their potential". In 2009, this philosophy became more specific embracing concepts of "student engagement, hands on learning and scaffolding". Dawn believed that teachers should focus on equality amongst students and lifelong learning. Her mean scores on the PBQ were 3.3 at the inception of the research and 3.4 at conclusion.

Although Dawn's first school was part of a dedicated public sector ICT initiative, the infrastructure provided was poor, and Dawn was frustrated by what she perceived as poor leadership in supporting ICT. For example, on arriving at the school in 2007 three computers were taken out of her classroom and situated in a laboratory. According to Dawn this was managed unprofessionally with the computers taking a long time to be connected to the school network. In early 2008, an interactive whiteboard was purchased, but was not connected by the time Dawn had left the school at the end of that year.

Dawn initially had a positive attitude towards ICT and wherever possible tried to incorporate it. In her response to the 2007 PBQ, Dawn maintained that:

ICT now must be utilised in the classroom as it is not only a necessary skill to learn, but the children are constantly exposed to multimedia and as a consequence respond and are more engaged when these technologies are used in the classroom.

Dawn felt that the interactive whiteboard in particular had the potential to transform her classroom by engaging her students. However, she exhibited frustration with the lack of ICT and support. For example, at an observation in $2008(n=17)$ she struggled to get the available ICT to work in the way she had planned (there were a number of technical problems that Dawn tried to solve without technical support). The lesson was on "the components of the computer" as she believed her students lacked this basic knowledge.

In February 2009, Dawn transferred to a metropolitan primary school, but again was hampered by a lack of ICT in her classroom. She had two computers but rarely used these because her class comprised of 25 students and Dawn was of the view that using the computers would create disharmony in the classroom. She did not have access to a projection device and physically going to a computer laboratory on a weekly basis was not seen as useful. Dawn is still positive about using ICT, but in 2009 remarked on becoming somewhat de-skilled because of her lack of access to ICT. She also has become disillusioned with what she sees as an apathetic school culture. For example, the following conversation at interview in 2009 exemplifies the different attitude that Dawn has from her peers on the potential of the interactive whiteboard:

[Dawn]: I was sitting around a table with the rest of my colleagues, who have been teaching for 20 or 30 years, and they straight away cut down the idea of using the interactive whiteboard. I was more of a feeling that I can't wait to get one.

[Interviewer]: Why do you think your colleagues expressed these attitudes?

[Dawn]: It is just too hard to set up. I think there is a little bit of "computing is great when it is working, but something always goes wrong." 
Both of the schools in which Dawn worked had an explicit focus on raising literacy and numeracy standards and increasing school attendance rates. The leadership in these schools did not see ICT as having a significant role in contributing to the achievement of these outcomes.

In summary, Dawn's experiences with ICT in her first three years of teaching have invariably been negative and this has led increasingly to a tendency not to use ICT. She has not been well equipped with ICT, nor has she been technically or pedagogically supported. Her peers are not particularly enthusiastic, and all of these factors have led to a situation where ICT "kind of gets put on the backburner" (Dawn, 2009).

\section{Mike}

Mike graduated in his early 20s gaining employment with a metropolitan primary school teaching at Year 6/7 level. He sees himself as one of the leaders in the school in terms of his ICT knowledge. Right from the first year of his teaching in 2007 Mike had his own laptop computer, and three computers were available in his classroom for student use. This increased to four by 2009. Mike also had access to a computer room once per week. In 2008, an interactive whiteboard was installed in Mike's classroom and he had no hesitation in using it. Mike's class sizes over the three years varied between 15 and 20.

In completing the PBQ in 2007, Mike suggested that his job was about creating "a positive atmosphere and motivating students to want to learn and to achieve their very best". By 2009, this philosophy had taken on some aspects of values education where Mike sought to model "honesty, genuineness, cooperative behaviours and caring". Mike believed that teachers should emphasise lifelong learning and student creativity. His scores in the PBQ were 3.3 at inception and 3.5 at the conclusion of the study.

In 2007, Mike exhibited an enthusiastic attitude to ICT:

I love it and if it were possible I would integrate it a lot more. Technology is constantly changing and students are using computing more and more; therefore we should embrace the opportunities they provide for students to learn.

In observing Mike in the classroom in 2008 ( $\mathrm{n}=18)$, he used the interactive whiteboard to show a PowerPoint presentation which he accessed from the world wide web. Students were unenthusiastic about this material, being keener to engage with nonICT based activities that were also prepared for the lesson. The computers were not used in this lesson, and at interview Mike revealed that the computers were seldom used except to reward early finishers, and "not for educational benefit" (Mike, 2008). At a later interview in 2008 he asserted that, with current class sizes, it is impossible to use the computers meaningfully for any student-directed activity other than for interactive games. At an observation in $2009(n=13)$ Mike provided a lesson on web searching that began with a 20 minute presentation using the interactive whiteboard as a projection device before moving to a computer lab for student independent work. The task centred on completing a worksheet after finding web-based information relating to a poem by Edgar Allen Poe called The Raven. Although positive about using ICT in his classroom, Mike's knowledge and skills remained static. He sees professional learning - "how can I teach them to get a deeper understanding" (Mike, 2009) - as his major barrier in being able to integrate ICT. In summary, Mike's 
experiences with ICT in his first three years of teaching have been faltering. This may be because he has used ICT mainly in teacher-centred ways and feels discouraged when his students fall short of reaching the deeper understandings for which he plans.

\section{Rashmi}

Rashmi was in her mid-20s when she obtained her first teaching appointment at a Catholic boys' school in metropolitan Perth teaching at Year 4 level. The school is well equipped and employs a principal who takes an active interest in supporting ICT. In 2007, Rashmi had access to five computers for student use and she also had a laptop and a fixed interactive whiteboard. On the same floor as Rashmi's class, is a library with a suite of 31 computers and another interactive whiteboard. A teacher librarian helps other teachers to use these ICT facilities effectively. Rashmi's class size varied from 28-32.

In 2007, Rashmi's described her philosophy of teaching as "challenging students in their zone of proximal development so they remain engaged and providing opportunities for students to become independent". At interview in 2009, this philosophy had become more focused on developing students' cooperative learning skills. On the PBQ Rashmi registered a mean of 3.8 at the inception of the study and 3.7 at its conclusion scoring particularly high mean scores on the cooperative learning scale (4.8 at inception and 4.7 at conclusion).

In completing the PBQ in 2007, Rashmi exhibited a positive attitude to ICT:

ICT is an important tool for learning. It is a medium in which students can learn content, present information, communicate with others. It is also vital to them to learn how to use it effectively as they will need it when they join the workforce.

In 2007, Rashmi was observed as she facilitated a session $(n=23)$ in which students collaboratively developed a PowerPoint presentation in the computer laboratory. A teacher-librarian assisted. In 2008, Rashmi provided a literacy lesson $(n=27)$ rotating four groups, one of which worked on the five computers in the classroom to develop a summary of an endangered species of animal. The students tended to focus on experimenting with fonts, graphics, backgrounds and borders and most did not finish the activity. One of the problems was that, as they rotated, students were largely left to their own devices to complete the task as Rashmi was using the interactive whiteboard with other groups. In 2009, Rashmi was observed as she skilfully led a whole-of-class interactive whiteboard session $(n=24)$ using a combination of her own materials with the Brainpop website to stimulate teacher-directed learning on the subject of quadrilaterals. Rashmi used the interactive aspects of the whiteboard by inviting students to engage with it, along with actively questioning the students about the content. Rashmi exhibited competent ICT skills in the three lessons observed between 2007 and 2009, and acknowledged the role of her university in preparing her how to use the Microsoft Office suite of products. At interview in 2007, she reported that her primary barrier to successfully integrating ICT was finding the time in the context of other pressures.

Rashmi's ICT skills improved over the three years of the study, particularly in using the interactive whiteboard where she became very proficient. However, she felt stressed with other priorities and as a result was irritated with what she saw as a constant push to use ICT: 
I have been a bit resistant to go into that world. It is the extra work. For me it is just another thing that I have to do (Rashmi, 2009).

In summary, Rashmi's experiences with ICT have been restrained. Although she felt compelled to use ICT, her preparation was always pressured by time and other priorities. As a result she invariably fell back on what she knew which generally involved accessing the world wide web for preparation, the interactive whiteboard for presentation and setting activities that involved student use of Word and PowerPoint. At the early stages of her teaching career, she did not see the benefits of harnessing ICT in ways that were in tune with her stated pedagogical beliefs which focused on cooperative learning.

\section{Discussion}

Dawn, Mike and Rashmi all claimed to hold pedagogical beliefs that are in tune with contemporary student-centred theories of learning. All three exhibited positive attitudes towards ICT in addition to demonstrating solid skills and high levels of confidence in using a basic suite of ICT tools. During the first three years of their teaching, however, their experiences in using ICT were inactive (Dawn), faltering (Mike) or restrained (Rashmi). None of the participants employed ICT in ways that enacted their pedagogical beliefs. The research found that participants faced a complex mix of constraints that, when combined, contributed to a lack of creativity in using ICT. The bridge framework, described earlier, provides a useful lens in which to diagnose the major constraints that participants in the research faced. These are now considered at individual, institutional and systemic levels.

\section{Individual constraints: Technological-Pedagogical-Content Knowledge}

Whilst Dawn, Mike and Rashmi felt that they already possessed sufficient technological knowledge to effectively integrate ICT, the research found a deficiency in the depth of technological knowledge required to enhance and support their stated pedagogy. The following comments, all made during interviews in 2009 exemplify a high level of technological confidence:

Dawn: In the staff room, all the teachers were struggling with how to do a PowerPoint. So while I don't feel I am proficient enough, that kind of makes me think that maybe I am better than most.

Mike: In my school I am the IT guy. I am the one with the most skills, so I go to professional learning and when I come back I teach them what I had been taught. It is my responsibility in the school.

Rashmi: I'm fine with technology. As soon as someone shows me something I can pick it up straight away. I just use my knowledge from all the other things that I know and apply it to that.

These sentiments suggest that all three participants perceived that they had adequate technological knowledge. However, in 2007 when asked whether they felt that ICT made a difference to the way teachers teach, responses tended to centre on the potential of ICT as a preparation and presentation tool:

Dawn: Yes I think it makes it a lot easier. You have a lot of resources through the Internet at your disposal. 
Mike: I use my laptop all of the time. I use it with a projector and show videos, PowerPoint presentations. Yes definitely I show kids - I've got it all here.

Rashmi: I have access to the Internet and the Smartboard software and I can access that at any time in my classes. I can quickly go to the Net and my boys can see me do that.

In contrast with their stated pedagogical beliefs, all three participants tended to employ ICT in teacher- rather than learner-centred ways. All held a worldview of ICT that emphasised the capacity of the world wide web to deliver resources, and none of the three demonstrated ways in which ICT could be harnessed to empower students with the locus of control.

According to Mishra and Koehler (2006) technological-pedagogical knowledge includes knowledge of the existence, components and capabilities of ICT, as they are used in a teaching and learning setting, and knowing how teaching may change as a result of using ICT. This may include an understanding of the range of tools that exist for a particular pedagogical dilemma, the ability to use a tool based upon its fitness, and the application of strategies to optimise the use of ICT tools for learning. These capabilities were lacking in Dawn, Mike and Rashmi and this typically resulted in its use being limited to an efficient aide (e.g. a narrow suite of software) or an extension device (e.g. web-based games).

Mishra and Koehler (2006) suggest that the synergy between technological knowledge, pedagogical knowledge and content knowledge requires an understanding of the representation of concepts using ICT; pedagogical techniques that use ICT in ways that allow learners to construct their own understandings and build on their prior knowledge; knowledge of what makes concepts difficult or easy to learn and how the appropriate use of ICT can challenge and add value to students' prior knowledge. In the three cases outlined in this paper, participants' limited knowledge of the range of ICT options available was an obvious barrier to the sophisticated use of ICT. More significantly, though, participants were not aware of what they did not know. All three teachers articulated beliefs in cooperative approaches to learning, but did not use ICT in ways that brought these beliefs to life. For example, at interview in 2008 when asked about the use of Web 2.0 tools in their teaching, Mike and Rashmi were lukewarm in their responses:

Mike: It would need to be a private thing that the kids could use in the class with me as a moderator. Otherwise it opens up to a lot of evils.

Rashmi: I need time to think how to fit things in and make sure that the kids are benefiting from it. Like with bloging, I don't really know what it is. I know it is like putting in information, writing a comment. I know I have seen it but I'm not really interested in it.

The reluctance of Mike and Rashmi to hand over the locus of control of ICT tools to students either through Web 2.0 technologies or in the form of cognitive tools for students to develop their own knowledge is consistent with findings from other literature (Cranmer, Potter \& Selwyn, 2008; Russell, et al., 2005). To return to the bridge framework, the quality of pedagogical reasoning processes tended to inhibit enactment of participants' beliefs and the realisation of their moral purpose. Between 2007 and 2009, nine observations were conducted involving Dawn, Mike and Rashmi. Not one exemplified ICT as promoting higher order thinking through, for example, solving ill-defined problems, or individualising learning through the representation of content in different ways. Technological, pedagogical and content knowledge were 
isolated, rather than integrated constructs. At interview in 2007, Dawn was asked whether she felt supported at her school in using ICT. Her reply was revealing:

Not terribly. As I have said there is more a focus on literacy and numeracy here.

Whatever else happens is a bonus.

The perceived focus on literacy and numeracy at the expense of ICT integration implies that both Dawn and her school did not see a link between ICT (technological knowledge) and improving literacy and numeracy outcomes (content knowledge). Technological knowledge appears to have been excluded from pedagogical reasoning processes. This is surprising given that much of the software available in Australia is targeted at improving outcomes in literacy and numeracy (e.g. the Learning Federation, Mathletics). On querying possible relationships between ICT and literacy/numeracy with the deputy principal, responses were vague as was strategic thinking about the way in which the Digital Education Revolution (an Australian Government ICT policy initiative) would impact on the school. This suggests a vacuum in school leadership in (a) interpreting the ICT policy landscape and (b) articulating this landscape to novice teachers in a way in which they can make concrete connections between technology, pedagogy and curriculum.

\section{Institutional constraints: School leadership}

At the institutional level, two factors combined to limit ICT use. These were lack of access to ICT infrastructure and unenthusiastic school cultures. Although some principals in this research achieved success in equipping and maintaining their schools, there was a wide variation in access to ICT infrastructure amongst participants, and the only schools that were adequately set up for the student use of ICT among the sample were private schools. This impacted on the extent to which participants were able to creatively use ICT for student-centred learning. In many cases, even the most enthusiastic participants could do little more than rotate students through the limited number of computers in their classrooms. In situations where a centralised computer laboratory was provided, participants struggled to gain appropriate and timely access. This state of affairs is also common in the literature (Groff \& Mouza, 2008).

On the face of it ICT infrastructure could be seen as the single most significant barrier that impacted on Dawn and Mike's ability to integrate ICT. However, this also indicates that, at the time of the study, the school leaders involved did not afford a high enough priority to ICT planning and implementation. Like teachers, principals and other school leaders could benefit from professional learning in understanding and evaluating the capacities of new digital technologies (Dawson \& Rakes, 2003; Russell, et al., 2005; Schiller, 2003). In a study involving 1,104 principals, Dawson and Rakes (2003) found that professional development opportunities for school leaders were lacking, particularly those that were long-term and specific to principals' needs.

The lack of ICT infrastructure that was made available to Dawn sent a strong message to her on how it was valued in the two schools in which she was located. Mike also indicated disillusionment at an interview in 2008:

The leadership of the school has very little knowledge. As far as leadership goes in the school, ICT is not a large focus so there is nowhere for me to go. 
The low-tech environments that Mike and Dawn found themselves in after graduating were typical across the research sample. Two out of three participants interviewed at the conclusion of the research did not have ready access to what they saw as a sufficient number of computers for students to engage in self-directed work. The study, therefore, identified a vacuum in ICT leadership in schools. This leadership vacuum was filled to varying degrees by a range of individuals including teachers, teacher librarians, ICT coordinators and IT managers. This led to some variation in interpretation on how ICT should be dealt with in schools. For example, mobile phones, iPods, social networking sites (e.g. Facebook) and peer-to-peer environments (e.g. YouTube) were banned in some schools, but seen as an interesting and creative opportunity in others. Many participants in the study, felt that policy was developed ad hoc and that school leaders were out of their depth.

In 2009, participants were asked whether they felt that their attitudes towards ICT were representative of the school in which they worked. Responses from Dawn, Mike and Rashmi suggested that their more experienced peers exhibited significant skill gaps:

Dawn: I think the biggest factor is age. We are confident of using the Internet and computers. We have been exposed to computers a lot more. These people here at the school are much older and have missed out on that so it is more difficult for them.

Mike: The older teachers have no idea to tell you the truth.

Rashmi: Older teachers might not have had much experience with technology. They don't know how to do things so everything is a lot harder for them.

Clearly, participants in the study did not have a great deal of confidence in their colleagues to respond to a new digital education paradigm. In defence of school leaders, though, managing the transition towards this new paradigm presents a difficult conundrum. If the focus is on ICT infrastructure, then there is a risk that teaching staff will not use this because of a lack of knowledge and skills. If the focus is on knowledge and skills then there is a risk that teaching staff, fully enthused, will be disappointed with the level of ICT infrastructure available to them in their classrooms. Empirical studies of school leaders in Canada (Isabelle \& Lapointe, 2003) and Ireland (McGarr \& Kearney, 2009) call upon school leaders to strike an appropriate balance between the provision of infrastructure and professional development, as well as finding ways of supporting both experienced and novice users of ICT.

\section{Systemic constraints: Structural reform}

At the systemic level, the research discerned some significant structural constraints that are embedded into deep-rooted thinking about the role and purpose of schools. For example, the idea that a "class" based upon "subjects" is the best way to help students construct knowledge is questionable in a ubiquitous knowledge-based society. The digital generation has access to a massive library of information through the world wide web and has shown an appetite for communicating and sharing understandings through bloging and file sharing (Barnes, Marateo, \& Pixy Ferris, 2007). Current students regularly use tools that help them to engage with knowledge outside the formal structure of the school. According to Somekh (2007) the institution of the school has been unsuccessfully playing catch-up in policy development terms since the emergence of ICT. One of the reasons, she argues (2004, p. 174) is that the power relations underpinning schools are fundamentally antipathetic to ICT: 
Schools are notoriously sites for control in which students are required to conform to a regime of practice which places the teacher in the role of authoritative individual and students in the role of members of an ignorant and potentially oppositional group.

If the creative use of ICT is about empowering students to set their own goals; repurpose and produce knowledge; develop communication networks; and find unique ways of solving problems, then the school, as described by Somekh above, is inappropriate for this purpose without fundamental structural reform. Mandated curriculum and high stakes assessment practices, for example, put pressure on teachers to get through the curriculum (Jordon, 2008; Lim \& Chai, 2008; Voogt, 2008) and teach for tests (Demetriadis, et al., 2003; Lim \& Chai, 2008; Selwyn, 2002; Voogt, 2008). The participants in this research experienced these pressures. For example, at interview in 2007, Rashmi remarked that the time that it would take her to integrate ICT was her biggest barrier:

I would love to do more [with ICT] but it's just time. Being a first year teacher I would like to be more innovative but I just want to consolidate what I have learnt. I would like to be challenged, but not when I have so much on my plate.

Ensuring that the curriculum was covered was particularly important to the beginning teachers in this study, many of whom were finding their way in linking appropriate pedagogical approaches with their content knowledge. A number of participants in the research reflected on curriculum content as being their most significant learning curve in the first couple of years of teaching. The demands of getting through the curriculum, in many cases, were seen as adversarial to the beliefs that participants claimed to hold. In such cases, if ICT were to be used at all, then their application was to support the goal of efficiently mediating content rather than for more creative uses, such as using ICT to promote communication or problem solving.

Lane (2004, p. 12) points out that "large scale assessments are the primary tools for communicating what teachers should be teaching and what students should be learning." However, she laments that, in recent attempts to address issues of accountability, cognitively rich assessment practices have been compromised. Zevenbergen, Dole and Wright (2004) propose six practices to guide assessment design: continuous gathering of evidence; integration of assessment with teaching; use of a range of tools; provision of opportunities for students to self-assess; collection of multiple forms of evidence; and provision of continual feedback to students. All of these are contrary to high-stakes assessment practices which reflects the needs of mass education (Erstad, 2008).

Assessment practices that measure the processes underpinning learning (e.g. performance-based assessment) provide an avenue to measuring higher order learning and ICT has been shown to enhance the quality of performance-based assessment through the use of digital portfolios (BECTA, 2007). However, the use of digital portfolios is embryonic in K-12 education. Paper-based, exam-driven assessment is still the dominant mechanism for gauging what students know. In a study of six teachers from two Singapore primary schools Lim and Chai (2008) concluded that the final frontier in ICT integration is likely to be the assessment system. This, it is argued, is antagonistic to both teachers' beliefs and their capacity to integrate ICT. The findings from the current research support this view. ICT was seldom used to enrich formative or summative assessment practices and most participants avoided using ICT in assessment. At an interview in 2009 Dawn raised serious equity issues around using ICT in an assessment mix: 
I think you need to be careful about what you are assessing - whether it's students' ICT skills or whether it's about the curriculum area. I think the different skill levels of students would get in the way of assessing curriculum outcomes.

Participants in this study did not consider digital portfolios for assessing their students, for two reasons. Firstly, most schools in the study were not technically set up to implement a system of digital portfolio assessment (i.e. ensuring that students have ready access to a network and software that can be used to develop and store digital artefacts); and secondly, most participants in the study were simply not acquainted with the concept of digital portfolios. The potential of using ICT to individualise learning and assessment was untapped mainly because of deficiencies in technological knowledge at both teacher and leadership levels in the school.

Using ICT in large class sizes can be problematic, particularly in situations where infrastructure is not robust. Participants in this study were sometimes cast in the role of technical support, and this function detracted from what they felt they were supposed to be doing (i.e. facilitating learning). The technical support function can be exacerbated by wide disparities in students' ICT skills and participants also alluded to a raft of behavioural issues that emerged, typically associated with increased levels of enthusiasm for using ICT. Large class sizes may be appropriate for transmissive models of teaching (e.g. lecturing), but as schools move towards 1:1 student-ICT device ratios, empowering students with ICT may require a re-think of support structures.

\section{Conclusions}

The variations in the socio-cultural contexts which participants were situated have advantages in terms of providing a rich data set. However, it is acknowledged that the themes extrapolated in this paper are underpinned by a relatively small number of cases, and therefore interpretations of findings to other contexts should be undertaken with caution. The rate at which existing ICT are improved and new ICT become available may also limit the usefulness of these findings particularly in the longer term. In saying this, there is still a need to resolve some difficult dilemmas in the terrain of ICT and technological and pedagogical knowledge, school leadership, curriculum, assessment, timetabling, and managing emerging technologies in the context of existing class sizes. The study found that a range of factors came in to play across individual, school and systemic domains. The following questions may assist in framing future research to inform ICT educational policy, and ultimately assist the take-up of ICT in Australian schools:

- How can teachers balance the demands of a crowded curriculum with providing students with opportunities to use ICT in ways that embrace the principles of lifelong learning?

- In what ways can students set their own goals within the context of stated curriculum goals? Can incidental learning be compatible with curriculum outcomes? Can ICT be used in creative ways to bridge the gap between planned and incidental learning?

- How can teachers be supported to integrate ICT in ways that promote individualised learning and higher order thinking even where limited ICT are available? 
- What changes can be made to the way in which students are assessed to help drive pedagogical decisions in a direction of higher order learning? And how can ICT assist in this process?

- What suite of support do principals need to help them provide the type of pedagogical leadership in ICT integration that will inspire their staff to push the boundaries of using ICT?

- Are there effective models of ICT use that cut across curricula and timetable constraints? Can these models be facilitated with appropriate and cost effective levels of content, pedagogical and technical support?

- How can educational leaders anticipate and respond to the rapidly changing ICT environment in measured ways to promote equal opportunity for students at the same time as encouraging innovation?

The evidence gathered through this study suggests that innovation through ICT is a complex matter that will require concerted effort over a long period of time. If the goal of transforming teaching and learning through ICT is to move beyond rhetoric, then there are many bridges to cross at individual, school and systemic levels of education.

\section{Acknowledgments}

The author wishes to acknowledge Murdoch University for providing support for the doctoral study that underpinned this paper: Bate, F. (2010). A longitudinal study of beginning teachers' pedagogical identity and their use of ICT. Unpublished PhD thesis, Murdoch University. http: / / wwwlib.murdoch.edu.au/adt/ browse/view/adt-MU20 100427.222635

\section{References}

Auld, G., Holkner, B., Fernando, A., Henderson, M., Romeo, G., Russell, G. et al. (2008). Exemplar schools using innovative learning technologies. Paper presented the Australian Computers in Education Conference (ACEC), Canberra, Australia. [verified 5 Dec 2010] http:/ / cemmx.educ.monash.edu.au/moodle/file.php/2/publications/ACEC2008_paper.pdf

Barnes, K., Marateo, R., \& Pixy Ferris, S. (2007). Teaching and learning with the Net generation. Innovate Journal of Online Education, 3(4). http: / innovateonline.info/pdf/vol3_issue4/ Teaching_and_Learning_with_the_Net_Generation.pdf

BECTA (2007). Impact study of e-portfolios on learning. Coventry, UK. [verified 5 Dec 2010] http: / / partners.becta.org.uk/ uploaddir/downloads/page_documents/research/impact_study_eportfolios.doc

Brown, M. (2004). Telling tales out of school: Why ICT is problematic. Unpublished Invitational address. CODENZ, Auckland College of Education.

Buehl, M. \& Fives, H. (2009). Exploring teachers' beliefs about teaching knowledge: Where does it come from? Does it change? The Journal of Experimental Education, 77(4), 367-408.

Cranmer, S., Potter, J. \& Selwyn, N. (2008). Learners and technology: 7-11. Coventry: BECTA. [verified 5 Dec 2010] http:/ / partners.becta.org.uk/upload$\mathrm{dir} /$ downloads/page_documents/research/learners_technology7-11.pdf

Cuban, L. (2001). Oversold and underused: Computers in the classroom. Cambridge, USA: Harvard University Press. 
Dawson, C. \& Rakes, G. (2003). The influence of principals' technology training on the integration of technology into schools. Journal of Research on Technology in Education, 36(1), 2949. http: / / cmapspublic2.ihmc.us/rid=1133304866250_585937957_2778/ dawson.pdf

Dede, C. (2008). Theoretical perspectives influencing the use of information technology. In J. Voogt \& G. Knezek (Eds.), International handbook of information technology in primary and secondary education (Vol. 1). New York: Springer.

Demetriadis, S., Barbas, A., Molohides, A., Palaigeorgiou, G., Psillos, D. \& Vlahavas, I. (2003). Cultures in negotiation: Teachers acceptance/resistance attitudes considering the infusion of technology into schools. Computers \& Education, 41(1), 19-37.

Erstad, O. (2008). Changing assessment practices and the role of IT. In J. Voogt \& G.Knezek (Eds.), International handbook of information technology in primary and secondary education (Vol. 1). New York: Springer.

Ertmer, P. (2005). Teacher pedagogical beliefs: The final frontier in our quest for technology integration? Educational Technology Research E Development, 53(4), 25-39.

Experience the Digital Education Revolution (2009). [viewed 28 Aug 2009] http: / / www.deewr.gov.au/Schooling/DigitalEducationRevolution/Pages/default.aspx

Fishman, B., Marx, R., Blumenfeld, P., Krajcik, J. \& Soloway, E. (2004). Creating a framework for research on systemic technology innovations. The Journal of the Learning Sciences, 13(1), 43-76.

Fives, H. \& Buehl, M. (2005). Accessing teacher beliefs about pedagogical knowledge: Developing an instrument. New Orleans: LA.

Freebody, P. \& Muspratt, S. (2007). The Le@rning Federation's digital resources: A preliminary study of access, use and value. [viewed 8 July 2009, verified 5 Dec 2010] http: / / www.thelearningfederation.edu.au / verve /_resources / dr_report_11_02_07.pdf

Frid, S. (2000). Constructivism and reflective practice in practice: Challenges and dilemmas of a mathematics teacher educator. Mathematics Teacher Education and Development, 2, 17-33.

Fullan, M. (1993). Why teachers must become change agents. Educational Leadership, 50(6), 12-17.

Gao, P., Wong, A., Choy, D. \& Wu, J. (2010). Developing leadership potential for technology integration: Perspectives of three beginning teachers. Australasian Journal of Educational Technology, 26(5), 643-658. http: / / www.ascilite.org.au/ajet/ ajet26/gao.html

Gillard, J. (2008). Digital Education Revolution. Speech given to the Australian Computers in Education Conference, October 2008. [verified 5 Dec 2010] http:/ / www.deewr.gov.au / Schooling/DigitalEducationRevolution/Documents / ACECMinistersSpeech_011008.pdf

Goos, M. (2005). A sociocultural analysis of the development of pre-service and beginning teachers' pedagogical identities as users of technology. Journal of Mathematics Teacher Education, 8, 35-59.

Goos, M. \& Bennison, A. (2002). Building learning communities to support beginning teachers' use of technology. Paper presented at the Annual Conference of the Australian Association for Research in Education, Brisbane, Australia. http: / / www.aare.edu.au/02pap/goo02058.htm

Goos, M. \& Bennison, A. (2007). Teacher learning in professional communities: The case of technology-enriched pedagogy in secondary mathematics education. Paper presented at the Annual Conference of the Australian Association for Research in Education, Fremantle, Australia. http: / / www.aare.edu.au/07pap/goo07562.pdf

Groff, J. \& Mouza, C. (2008). A framework for addressing challenges to classroom technology use. AACE Journal, 16(1), 21-46.

Harris, J., Mishra, P. \& Koehler, M. (2009). Teachers' technological pedagogical content knowledge and learning activity types: Curriculum-based technology integration reframed. Journal of Research on Technology in Education, 41(4), 393-417. http:/ / www.eric.ed.gov:80/ ERICWebPortal/ contentdelivery/ servlet/ ERICServlet?accno=EJ844273 
Hofer, B. (2006). Domain specificity of personal epistemology: Resolved questions, persistent issues, new models. International Journal of Educational Research, 45, 85-95.

Hughes, J., Thomas, R. \& Scharber, C. (2006). Assessing technology integration: The RAT replacement, amplification, and transformation - framework. Technology and Teacher Education Annual, 3, 1616-1620.

Isabelle, C. \& Lapointe, C. (2003). Start at the top: Successfully integrating information and communication technologies in schools by training principals. Alberta Journal of Educational Research, 49(2). [verified 5 Dec 2010] http: / / ajer.synergiesprairies.ca/ajer/index.php/ajer/article/view/367/359

Jamieson-Proctor, R., Burnett, P., Finger, G. \& Watson, G. (2006). ICT integration and teachers' confidence in using ICT for teaching and learning in Queensland state schools. Australasian Journal of Educational Technology, 22(4), 511-530. http:/ / www.ascilite.org.au/ajet/ajet22/jamieson-proctor.html

Jonassen, D. (2002). Computers as mindtools for schools. New Jersey: Prentice-Hall Inc.

Jonassen, D., Peck, K., \& Wilson, B. (1999). Learning with technology: A constructivist perspective. Upper Saddle River, NJ: Prentice Hall.

Jordon, K. (2008). It's a matter of context: Teacher use of ICT within a senior secondary school in Victoria. Paper presented at the Australian Computers in Education Conference (ACEC), Canberra, Australia.

Judson, E. (2006). How teachers integrate technology and their beliefs about learning: Is there a connection? Journal of Technology and Teacher Education, 14(3), 581-597.

Kadel, R. (2005). How teacher attitudes affect technology integration. Learning $\mathcal{E}$ Leading with Technology, 32(5), 34-47.

Kompf, M. (2005). Information and communications technology (ICT) and the seduction of knowledge, teaching and learning: What lies ahead for education. Curriculum Inquiry, 35(2), 231-233.

Lane, S. (2004). Validity of high-stakes assessment: Are students engaged in complex thinking? Educational Measurement, Issues and Practice, 23(3), 6-14.

Levin, T. \& Wadmany, R. (2008). Teachers' views on factors affecting effective integration of information technology in the classroom: Developmental scenery. Journal of Technology and Teacher Education, 16(2), 233-263.

Lim, C. P. \& Chai, C. S. (2008). Teachers' pedagogical beliefs and their planning and conduct of computer-mediated classroom lessons. British Journal of Educational Technology, 39(5), 807-828.

Maddux, C., LaMont Johnson, D. \& Willis, J. (2001). Educational computing: Learning with tomorrow's technologies (3rd ed.). Needham Heights, MA: Allyn \& Bacon.

MCEETYA (2006). Statements of learning for information and communication technologies. Carlton, Victoria: Curriculum Corporation. [verified 6 Dec 2010] http: / / www.curriculum.edu.au/verve/_resources/SOL06_ICT.pdf

McGarr, O. \& Kearney, G. (2009). The role of the teaching principal in promoting ICT use in small primary schools in Ireland. Technology, Pedagogy and Education, 18(1), 87-102.

Mishra, P. \& Koehler, M. (2006). Technological pedagogical content knowledge: A framework for teacher knowledge. Teachers College Record, 108(6), 1017-1054.

Pegg, J., Reading, C. \& Williams, M. (2007). Partnerships in ICT learning study: Full report. Canberra: Department of Science, Education and Training. [verified 6 Dec 2010] http:/ / www.deewr.gov.au/Schooling/DigitalEducationRevolution/Documents/pictl_full_report1.pdf

Phelps, R. \& Maddison, C. (2008). ICT in the secondary visual arts classroom: A study of teachers' values, attitudes and beliefs. Australasian Journal of Educational Technology, 24(1), 114. http: / / www.ascilite.org.au/ajet/ajet24/phelps.html 
Russell, M., Bebell, D. \& O'Dwyer, L. (2005). Tracking the arc of new teachers' technology use. In C. Vrasidas \& G. Glass (Eds.), Preparing teachers to teach with technology (pp. 45-63). Greenwich, Connecticut: Information Age Publishing.

Schiller, J. (2003). Working with ICT: Perceptions of Australian principals. Journal of Educational Administration, 41(2), 171-176.

Selwyn, N. (2002). Telling tales on technology: Qualitative studies of technology and education. Aldershot: Ashgate Publishing Limited.

Shulman, L. (1987). Knowledge and teaching: Foundations of the new reform. Harvard Educational Review, 55, 1-22.

Somekh, B. (2004). Taking the sociological imagination to school: An analysis of the (lack of) impact of information and communications technologies on education systems. Technology, Pedagogy and Education, 13(2), 163-179.

Somekh, B. (2007). Pedagogy and learning with ICT: Researching the art of innovation. London: Routledge.

Somekh, B. (2009). Factors affecting teachers' pedagogical adoption of ICT. In J. Voogt \& G.Knezek (Eds.), International handbook of information technology in primary and secondary education (Vol. 1). New York: Springer.

Steketee, C. (2005). Integrating ICT as an integral teaching and learning tool into pre-service teacher training courses. Issues in Educational Research, 15(1), 101-113. http: / / www.iier.org.au/iier15/ steketee.html

Sutherland, R., Robertson, S. \& John, P. (2009). Improving classroom learning with ICT. London: Routledge.

Vannatta, R. \& Fordham, N. (2004). Teachers' dispositions as predictors of classroom technology use. Journal of Research on Technology in Education, 36(3), 231-250.

Voogt, J. (2008). IT and curriculum processes. In J. Voogt \& G. Knezek (Eds.), International handbook of information technology in primary and secondary education (Vol. 1). New York: Springer.

Voogt, J. \& Knezek, G. (2008). IT in primary and secondary education: Emerging issues. In J. Voogt \& G. Knezek (Eds.), International handbook of information technology in primary and secondary education (Vol. 1). New York: Springer.

Webb, M. \& Cox, M. (2004). A review of pedagogy rated to information and communications technology. Technology, Pedagogy and Education, 13(3), 235-286.

Western Australian Department of Education and Training (2006). Teacher ICT skills: Evaluation of the Information and Communication Technology (ICT) knowledge and skill levels of Western Australian government school teachers. Perth: Western Australian Department of Education and Training.

Zevenbergen, R., Dole, S. \& Wright, R. (2004). Teaching mathematics in the primary school. St Leonards, Australia: Allen \& Unwin.

Frank Bate $P h D$ is Lecturer, Medical Education in the School of Medicine, and a senior lecturer in the School of Education, University of Notre Dame, Fremantle, Western Australia. Email: frank.bate@nd.edu.au 